DOI: https://doi.org/10.36910/6775-2524-0560-2021-42-04

УДК: 629.78.048.3

Булавка Сергій Сергійович, аспірант

Національний університет кораблебудування імені адмірала Макарова, Машинобудівний навчально-науковий інститут, кафедра кондиціонування і рефрижерації, Україна

\title{
ПІДВИЩЕННЯ ЕФЕКТИВНОСТІ ПЕРЕДСТАРТОВОЇ СИСТЕМИ ТЕРМОСТАТУВАННЯ ПОВІТРЯ КОСМІЧНИХ АПАРАТІВ
}

Булавка С. С. Підвищення ефективності передстартової системи термостатування повітря космічних апаратів. У роботі було запропоновано модифіковані структурні схеми передстартової системи термостатування повітря космічних апаратів для підвищення іiі ефективності та виконано порівняльну оцінку. Теоретичні результати, отримані для передстартової системи термостатування повітря космічних апаратів показали, що розроблені структурні схеми мають більшу ефективність роботи у порівнянні з існуючою, оскільки відхилення значень розподілення градієнту температур за довжиною по осі при температурі зовнішнього середовища в 20 і $30^{\circ} \mathrm{C}$ не перевищує $16,7 \%$. Отримані результати вказують на доцільність в застосуванні запропонованої модифікованої схеми передстартової системи термостатування повітря з підпірним дроселем та фільтрами грубого і тонкого очищення.

Ключові слова: космічні апарати, передстартова система термостатування, ефективність, ракети-носії, підпірний дросель, фільтри грубого і тонкого очищення

Булавка С.С. Повышение эффективности предстартовой системы термостатирования воздуха космических аппаратов. В работе предложены модифицированные структурные схемы предстартовой системы термостатирования воздуха космических аппаратов для повышения ее эффективности и выполнено сравнительную оценку. Теоретические результаты, полученные для предстартовой системы термостатирования воздуха космических аппаратов показали, что разработанные структурные схемы имеют большую эффективность работы по сравнению с существующей, поскольку отклонения значений распределения градиента температур по длине оси при температуре окружающей среды в 20 и $30^{\circ} \mathrm{C}$ не превышают $16,7 \%$. Полученные результаты указывают на целесообразность в применении предложенной модифицированной схемы предстартовой системы термостатирования воздуха с подпорным дросселем и фильтрами грубой и тонкой очистки.

Ключевые слова: космические аппараты, предстартовая система термостатирования, эффективность, ракетыносители, подпорный дроссель, фильтры грубой и тонкой очистки

Bùlavka S. S. Improving the efficiency of the pre-launch thermostat system the air of spacecraft. The paper proposes modified structural diagrams of the prelaunch thermostat system the air of spacecraft to increase its efficiency and makes a comparative assessment. Theoretical results obtained for the pre-launch thermostat system the air of spacecraft showed that the developed structural schemes have greater efficiency compared to the existing one, since the deviations of the distribution of the temperature gradient along the axis at an ambient temperature of 20 and $30^{\circ} \mathrm{C}$ do not exceed $16.7 \%$ The results obtained indicate the feasibility in applying the proposed modified scheme of the pre-launch thermostat system the air with a retaining choke and coarse and fine filters.

Keywords: spacecraft, pre-launch thermostat system, efficiency, launch vehicles, booster throttle, coarse and fine filters.

Постановка проблеми. Космічна галузь України потребує забезпечення конкурентоспроможності розробляємих космічних ракетних комплексів (КРК) з використанням ракет-носіїв (РН) на світовому ринку космічних послуг. РН розглядаються як потенційні носії відповідно до національних програм України та інших держав для реалізації супутникових програм i систем. Одним 3 найважливіших завдань $€$ забезпечення збережуванності $\mathrm{i}$ працездатності космічного апарату (КА) на всіх етапах його виведення в космос: при транспортуванні 3 монтажно-випробувального комплексу до стартового майданчика, при підготовці до старту і під час польоту РН на активній ділянці траєкторії. Складовою частиною цієї проблеми є створення комфортних температурних умов для КА. У всіх випадках збереження КА забезпечується огорожею від впливу на нього теплових і газодинамічних навантажень за допомогою головного обтічника відсіку КА. Крім того в наземних умовах температурний режим у відсіку КА підтримується за допомогою системи термостатування (СТС), що здійснює примусову вентиляцію в відсіку $[2,3]$. Досвід комерційного використання РН [2-5] показав, що в зв'язку з вимогою створення більш комфортних умов для сучасних КА виникали завдання по доопрацюванням і модернізації штатних СТС. Все більш активне використання РН в рамках комерційних проектів, їх модернізація в частині збільшення розмірів відсіку КА, створення нових РН обумовлюють актуальність нового підходу до проблем модернізації та розробки систем термостатування.

Аналіз останніх досліджень і публікацій. Аналіз конструктивних особливостей існуючих відсіків КА показує, що ці системи розроблялися для роботи з герметичними апаратами, коли в 
відсіку здійснюється тільки контроль температурно-вологісного режиму. Термостатне повітря у відсіки КА подається через щілинні газоводи, що формують інтенсивні пристінні струмені, швидкість яких на виході з щілинних колекторів досягає $12 \ldots 16 \mathrm{~m} / \mathrm{c}$. Основна маса повітря рухається в пристінних струменях повз КА, потім розгортається в місці зіткнення струменів $\mathrm{i}$ рухається уздовж корпусу головного обтічника до вихідних отворів на його конічній частини [4, 5]. Поблизу поверхонь КА створюються значні застійні області, в яких практично відсутня швидкість руху повітря. У цих умовах коефіцієнти конвективної тепловіддачі 3 поверхні КА мають значення на рівні природної конвекції $\left(3 \ldots 5 \mathrm{BT}^{\cdot} \mathrm{M}^{-2} \mathrm{~K}^{-1}\right)$, і завдання стабілізації температури КА здійснюється за рахунок збільшення подачі термостатного повітря в відсік і теплознімання пристінними струменями [6,7]. У той же час поверхні вузлів КА, що знаходяться в зоні пристінних струменів, можуть піддаватися значному газодинамічному впливу термостатного повітря (V>3-4 м/c).

Працездатність сучасних негерметичних КА, що виготовляються з матеріалів з невисокими механічними характеристиками, в значній мірі буде залежати від інтенсивності впливу на нього навколишнього середовища в відсіку [2-5]. Тому в відсіку повинні забезпечуватися комфортні умови для КА: низький рівень теплового і газодинамічного впливу на КА за рахунок зниження в $1,5 \ldots 2$ рази теплопотоку на КА в порівнянні з існуючими нормами при одночасному обмеженні швидкості термостатного повітря поблизу поверхні КА до $1,5 \ldots 2 \mathrm{~m} / \mathrm{c}$; повинні виконуватися підвищені вимоги до чистоти простору відсіку (наприклад, на рівні федерального стандарту США Fed Std 209E).

При польоті РН на активній ділянці траєкторії через вихідні люки СТС здійснюється скидання надлишкового тиску повітря з відсіку КА в навколишній простір (дренування). При зміні кута атаки або зміні швидкісного режиму при числах Маха $\mathrm{M} \approx 1$ можлива різка зміна надлишкового тиску на поверхні відділення КА. При відсутності лічильників води на вихідних люках СТС можливо втікання повітря з навколишнього середовища в відсік КА $[2-4,6]$. Перед відділенням КА від РН до моменту скидання головного обтічника за рахунок дренування повітря повинне бути забезпечене вирівнювання тиску в відсіку з тиском навколишнього простору. В іншому випадку надмірна різниця тисків призведе до впливу істотних газодинамічних навантажень на КА в момент скидання обтічника. На основі аналізу конструктивних особливостей систем термостатування КА [5, 7-10] повинні бути сформульовані нові вимоги до характеристик даної системи. Раніше вимоги до СТС визначали технічні умови на параметри термостатного повітря - межі зміни температури і вологості повітря, об'ємна витрата повітря, надлишковий тиск у відсіку КА в режимі наземного термостатування і в момент скидання головного обтічника [2-5, 9, 11]. Нові, сучасні вимоги до СТС, складаються в додатковому нормуванні наступних характеристик роботи СТС:

- рівень середніх коефіцієнтів теплообміну при охолодженні КА загальною системою термостатування;

- рівень середніх швидкостей руху термостатного повітря поблизу поверхонь КА;

- чистота простору відсіку КА на рівні міжнародних стандартів;

- рівень середніх коефіцієнтів теплообміну і швидкості повітря для пристроїв локального обдування теплонапружених вузлів КА.

Додаткові вимоги до СТС можуть бути задоволені наступними конструктивними удосконаленнями існуючих СТС [5, 7-11]:

- встановленням додаткових підвідних патрубків, що дозволить при необхідності збільшити кратність повітрообміну в відсіку КА;

- установкою лічильників води на вихідних люках СТС і мембранних фільтрів на перегородках між відсіком КА і приладовим відсіком (ПО);

- установкою автономних пристроїв локального обдування теплонапружених елементів КА;

- установкою грат, перфорованих екранів, панелей, що забезпечують більш рівномірний обдув КА.

Важливою умовою запуску РН є забезпечення температурно-вологісного режиму в іï відсіках при проведенні передстартової підготовки перед пуском.

CTC під час проектування вимагає рішень багатьох завдань, спрямованих на забезпечення необхідних значень чистоти, тиску, температури, витрати і температури точки роси.

Формулювання цілей статті. У роботі необхідно виконати розробку і удосконалення передстартової системи термостатування повітря КА з метою підвищення ії̈ ефективності. 
Виклад основного матеріалу. Відповідно до існуючих систем термостатування повітря КА приведемо на рис. 1 структурну схему. Для наведеної схеми було обране обладнання модуля передстартової системи термостатування, а також додаткове обладнання, яке складається з модуля джерела живлення, системи автоматизованого управління і контролю.

Приведена структурна схема передстартової системи термостатування повітря КА (рис. 1) може бути модифікована, а саме: перед нагрівачем встановити підпірний дросель, який забезпечить необхідний тиск осушення повітря з деяким запасом. Дана модифікована структурна схема передстартової системи термостатування повітря КА наведена на рис. 2.

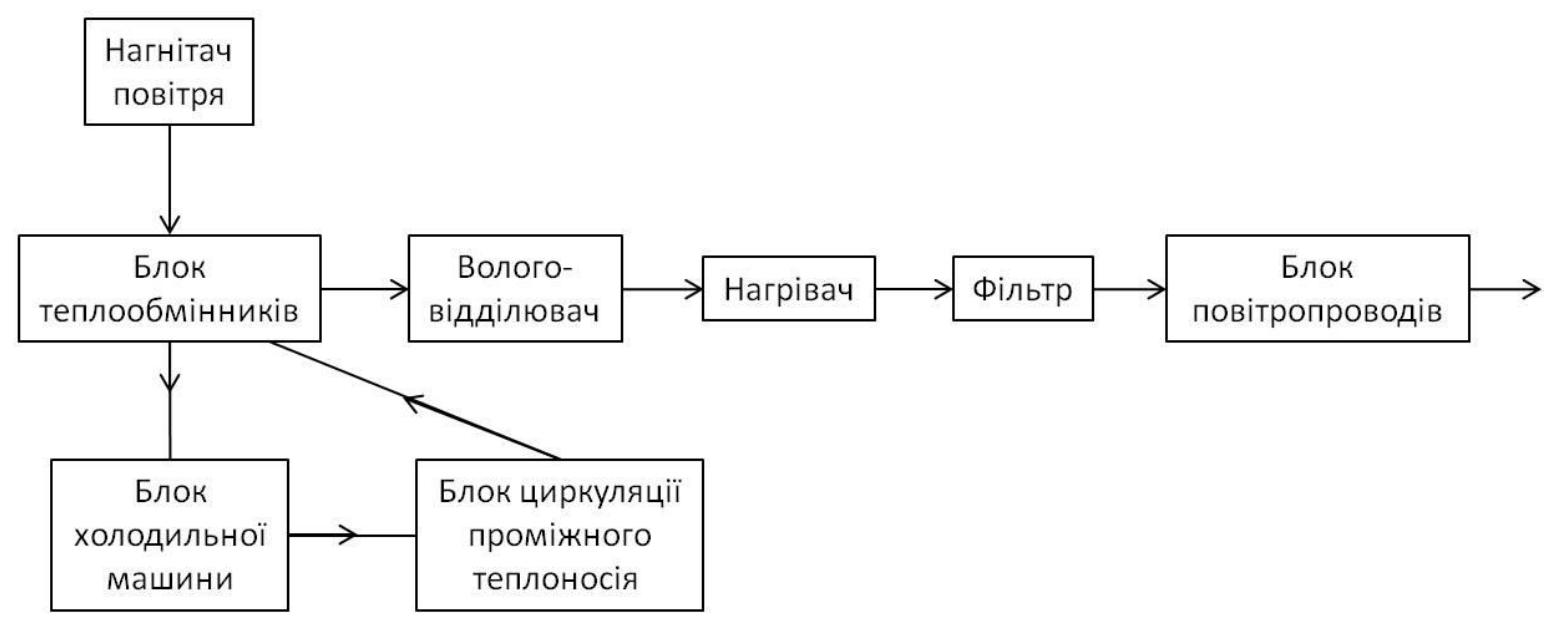

Рис. 1. Структурна схема передстартової системи термостатування повітря КА

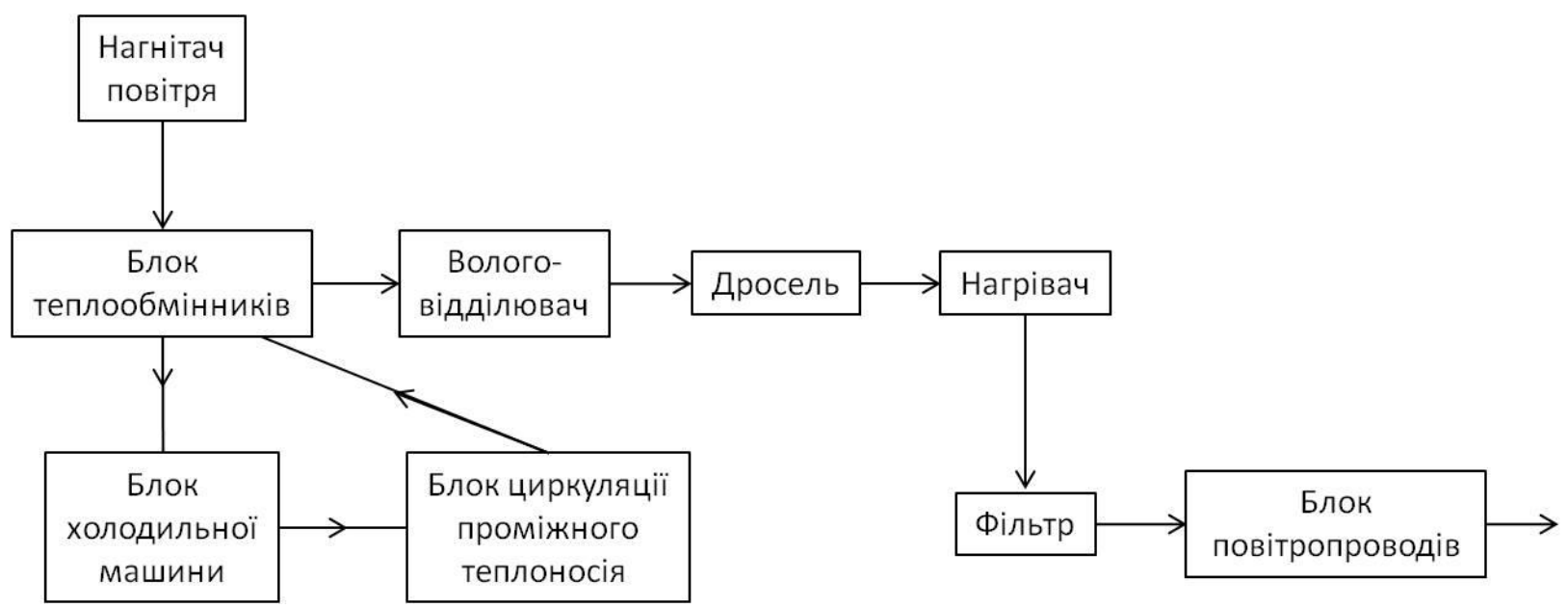

Рис. 2. Модифікована структурна схема передстартової системи термостатування повітря КА $з$ підпірним дроселем

Крім того, в роботі пропонується виконати ще одну модифікацію структурної схеми, яка полягає у встановленні перед транспортно-установчим агрегатом блоку фільтрів: грубого i тонкого очищення. Таку модифіковану структурну схему наведемо на рис. 3 . 


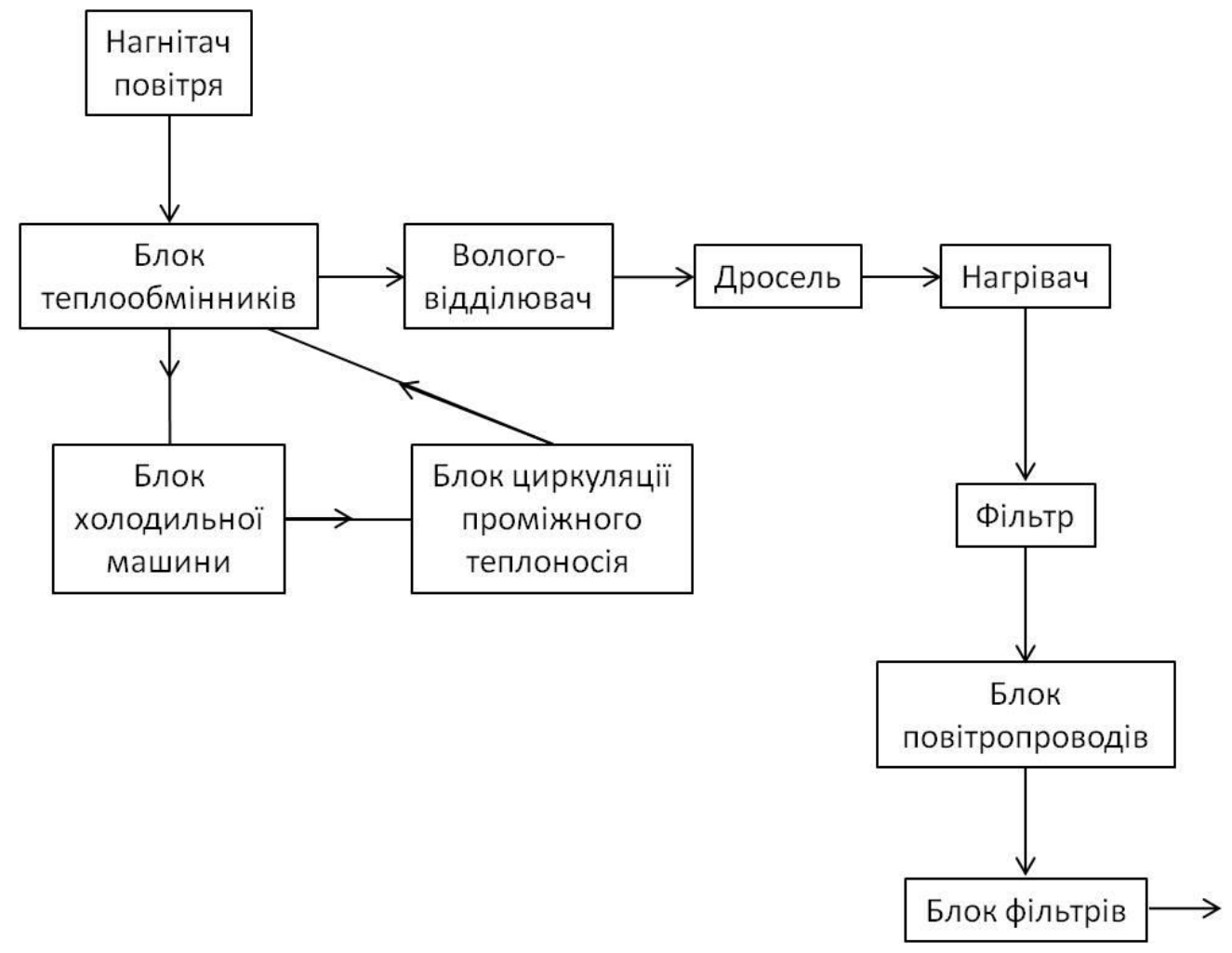

Рис. 3. Модифікована структурна схема передстартової системи термостатування повітря КА з підпірним дроселем та фільтрами грубого і тонкого очищення

Запропоноване установлення блоку фільтрів пов'язане з вимогами до чистоти подаваємого повітря за стандартом ISO 14644-1. Дана модифікація структурної схеми передстартової системи термостатування повітря КА дозволить контролювати якість повітря (температуру і вологість) безпосередньо на об'єктах моніторингу.

Для приведених структурних схем передстартової системи термостатування повітря КА далі виконаємо порівняння отриманої якості безпосередньо на окремих об'єктах. Схему підводу термостатуючого повітря до характерних відсіків РН приведемо на рис. 4.

3 рис. 4 можемо бачити наявність вхідних та вихідних отворів, що розташовані в характерних відсіках РН. До вхідних отворів приєднані повітропроводи від модуля термостатування, а у внутрішньому просторі відсіків РН розташовані дифузори, які виконують роль по напрямленню повітря. Конструкція дифузорів впливає на швидкість розповсюдження термостатуючого повітря та вихідну температуру внутрішнього середовища $\mathrm{PH}$.

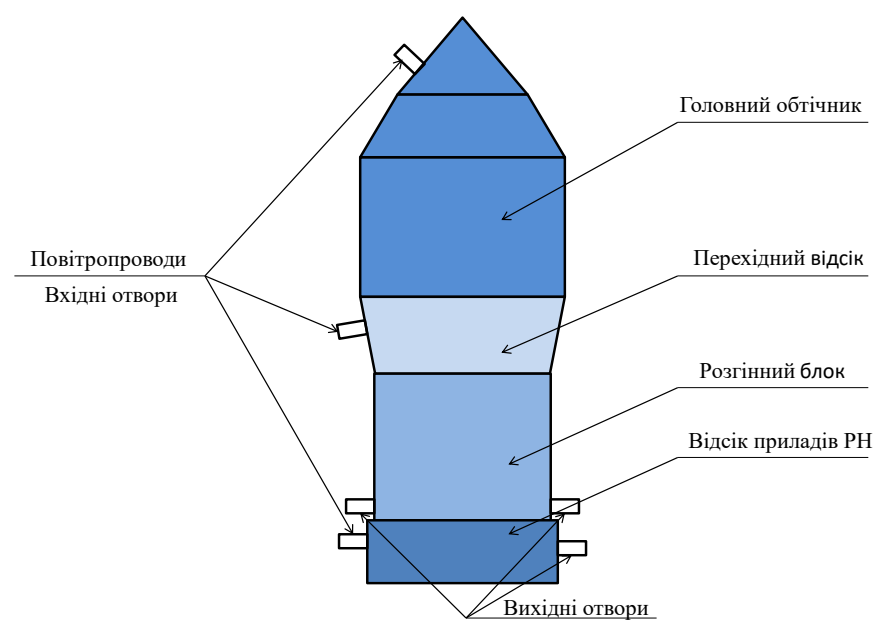

Рис. 4. Схема підводу термостатуючого повітря до характерних відсіків РН 
Для вирішення завдання по встановленню ефективності передстартової системи термостатування повітря використане комп'ютерне моделювання за допомогою програмного комплексу FlowVision, в якому реалізовано рішення рівнянь руху в'язкого стисненого газу. При вирішенні даної задачі використовуються модифікована $k$ модель і автоматична генерація сіток. Для вирішення поставленого завдання вихідною $€$ наступна інформація:

- загальна модель внутрішнього розташування відсіків і блоків РН (рис. 4);

- витрати термостатуючого повітря, що подається до головного обтічника, розгінного блоку та відсіку приладів РН складають 7000, 5000 та 4500 м³/год відповідно;

- температура повітря термостатування складає $10 \ldots 25^{\circ} \mathrm{C}$.

Крім того, у вихідну інформацію закладена необхідність забезпечення швидкості течії повітря термостатування у внутрішньому середовищі головного обтічника $\mathrm{PH}$ на рівні до $30 \mathrm{~m} / \mathrm{c}$ на відстані, що не перевищує 5,5 м по осі РН і виконання мінімізації надходження змішаного повітря з розгінних блоків через перехідний відсік в зону головного обтічника, де розташовано КА.

Приведемо на рис. 5 результати дослідження залежності градієнта температури за довжиною по осі РН при застосуванні структурної схеми передстартової системи термостатування повітря, що наведена на рис. 1 та за умови різних значень температур зовнішнього середовища та вимог щодо значень температури повітря термостатування.

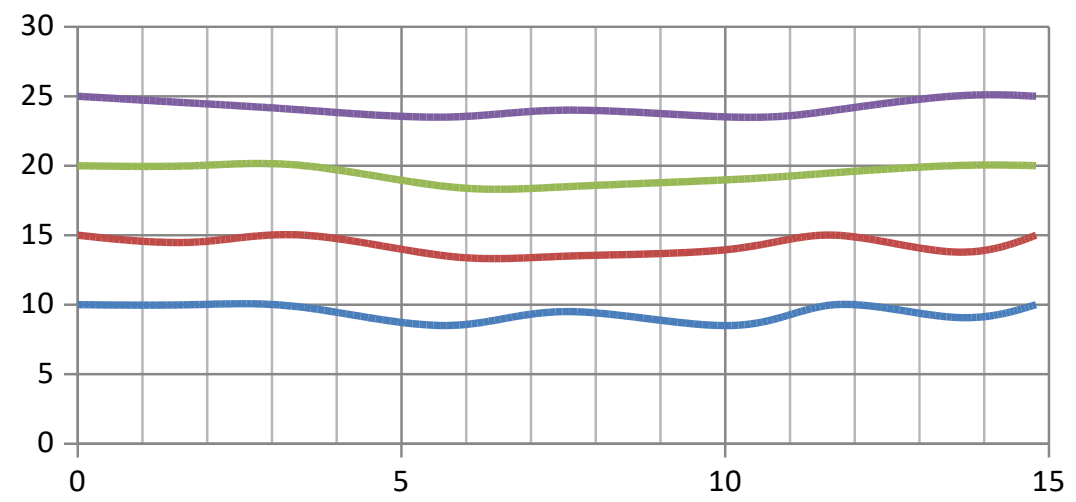

a

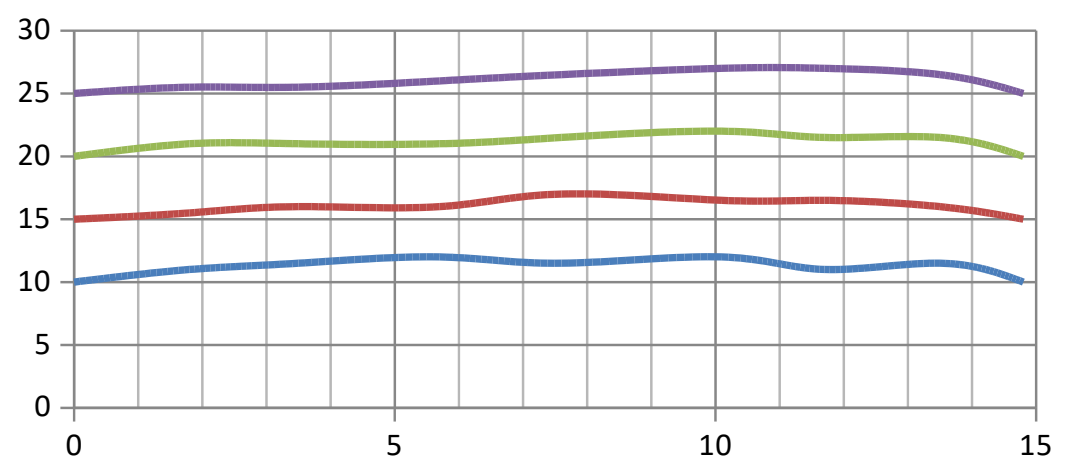

6

Рис. 5. Градієнт температур за довжиною по осі РН при застосуванні структурної схеми передстартової системи термостатування повітря, що наведена на рис. 1 та при температурі зовнішнього середовища $20^{\circ} \mathrm{C}$ (а) і $30^{\circ} \mathrm{C}$ (б) і необхідній температурі термостатування: $1-10^{\circ} \mathrm{C} ; 2$ $15^{\circ} \mathrm{C} ; 3-20^{\circ} \mathrm{C} ; 4-25^{\circ} \mathrm{C}$

Також отримані результати дослідження (рис. 6) залежності градієнта температури за довжиною по осі РН при застосуванні модифікованої структурної схеми передстартової системи термостатування повітря з підпірним дроселем, що наведена на рис. 2 та за умови різних значень температур зовнішнього середовища та вимог щодо значень температури повітря термостатування. 


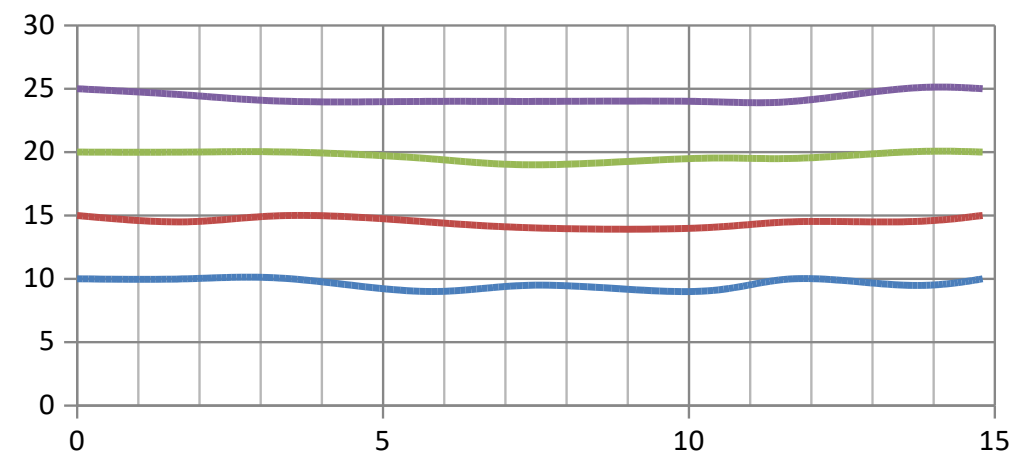

a

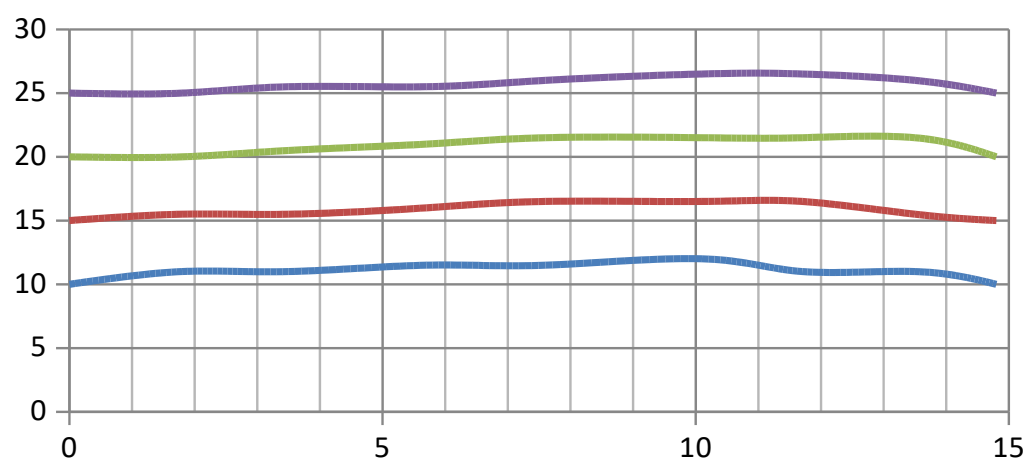

6

Рис. 6. Градієнт температур за довжиною по осі РН при застосуванні модифікованої структурної схеми передстартової системи термостатування повітря з підпірним дроселем, що наведена на рис. 2 та при температурі зовнішнього середовища $20^{\circ} \mathrm{C}$ (a) і $30^{\circ} \mathrm{C}$ (б) і необхідній температурі термостатування: $1-10^{\circ} \mathrm{C} ; 2-15^{\circ} \mathrm{C} ; 3-20^{\circ} \mathrm{C} ; 4-25^{\circ} \mathrm{C}$

На рис. 7 приведені результати дослідження залежності градієнта температури за довжиною по осі РН при застосуванні модифікованої структурної схеми передстартової системи термостатування повітря 3 підпірним дроселем та фільтрами грубого і тонкого очищення, що наведена на рис. 3 та за умови різних значень температур зовнішнього середовища та вимог щодо значень температури повітря термостатування.

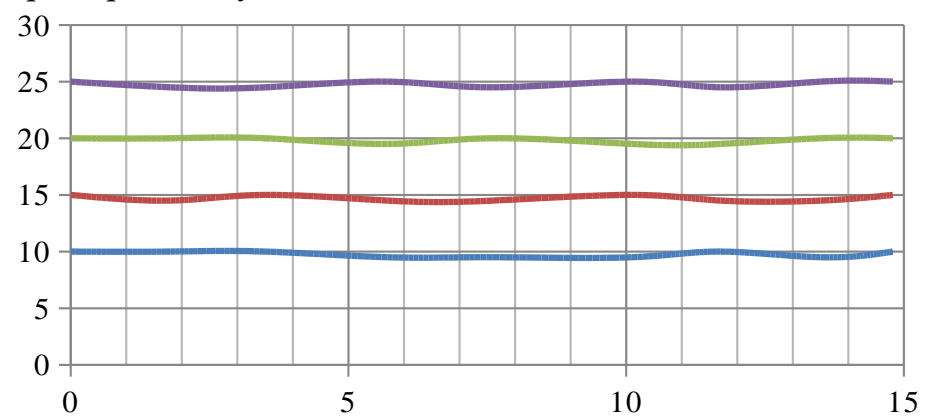

a

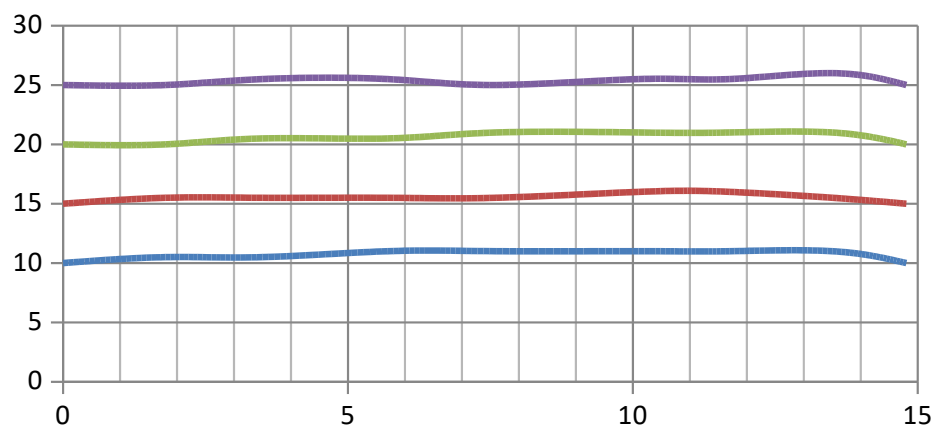


Рис. 7. Градієнт температур за довжиною по осі РН при застосуванні модифікованої структурної схеми передстартової системи термостатування повітря 3 підпірним дроселем та фільтрами грубого і тонкого очищення, що наведена на рис. 3 та при температурі зовнішнього середовища $20^{\circ} \mathrm{C}$ (а) і $30^{\circ} \mathrm{C}$ (б) і необхідній температурі термостатування: $1-10^{\circ} \mathrm{C} ; 2-15^{\circ} \mathrm{C} ; 3-$ $20^{\circ} \mathrm{C} ; 4-25^{\circ} \mathrm{C}$

Спостерігається практично однакова динаміка розподілення градієнту температур повітря термостатування за довжиною по осі $\mathrm{PH}$ (рис. 5-7), як при температурі зовнішнього середовища в $20^{\circ} \mathrm{C}$, так і в $30^{\circ} \mathrm{C}$.

Висновки. У роботі для підвищення ефективності передстартової системи термостатування повітря КА запропоновано модифіковані структурні схеми, на основі яких виконано порівняльну оцінку температури повітря безпосередньо на об'єктах КА.

Наведені теоретичні результати модифікованих структурних схем передстартової системи термостатування повітря КА показали наступне.

Для наведеної структурної схеми (рис. 1) розподілення градієнту температур за довжиною по осі РН при температурі зовнішнього середовища в 20 і $30^{\circ} \mathrm{C}$ відрізняється на $6,4 \ldots 17,6 \%$. Для приведеної структурної схеми (рис. 2) розподілення градієнту температур за довжиною по осі РН при температурі зовнішнього середовища в 20 і $30^{\circ} \mathrm{C}$ відрізняється на $4,2 \ldots 16,7 \%$. Для структурної схеми (рис. 3) розподілення градієнту температур за довжиною по осі РН при температурі зовнішнього середовища в 20 і $30^{\circ} \mathrm{C}$ відрізняється на $2,0 \ldots 9,1 \%$.

Отримані результати вказують на доцільність в застосуванні модифікованої схеми передстартової системи термостатування повітря з підпірним дроселем та фільтрами грубого і тонкого очищення.

\section{Список бібліографічного опису}

1. Галинский В.П., Тимошенко В.И. (1998). Проблемы создания научно-методического обеспечения по аэродинамике ракет-носителей. Космічна наука і технологія. 4, № 2/3. С. 64-72.

2. Дегтяренко В. И. (1999). Определение параметров воздуха в отсеке ракеты на активном участке полета. Техническая механика. № 1. С. 17-22.

3. Тимошенко В.И., Галинский В.П., Белоцерковец И.С. (1998). Проблемы математического моделирования процессов аэрогазодинамики ракет-носителей. Вісник Дніпропетровського університету. Механіка. Дніпропетровськ, Вип. 1. С. 37-52.

\section{References}

1. Carbonell, D., Cadafalch, J., \& Consul, R. (2011). A Transient Model for Radiant Heating and Cooling Terminal Heat Exchangers Applied to Radiant Floors and Ceiling Panels. Proceedings of the ISES Solar World Congress 2011. doi: 10.18086/swc.2011.26.03.

2. Kumar, A. V., Kumar, O. A., \& K. Bala Kumar| M. Dinesh Kumar. (2019). Preparation of Fan Coil Unit using Revit Software. International Journal of Trend in Scientific Research and Development, Volume-3(Issue-3), 1382-1387. doi: 10.31142/ijtsrd23376.

3. Chen, J., \& Xie, W. W. (2012). Analysis on Load-Undertaking of Fan Coil Unit with Fresh Air System. Advanced Materials Research, 614-615, 678-681. doi: 10.4028/www.scientific.net/amr.614-615.678.

4. Du, Y. (2014). Feasibility Analysis of Radiant Floor Cooling and Heating System Applications. Applied Mechanics and Materials, 716-717, 428-430. doi: 10.4028/www.scientific.net/amm.716-717.428.

5. Budiaková, M. (2016). Indoor Environment Influenced by Radiant Effect of Floor Heating. Applied Mechanics and Materials, 824, 218-225. doi: 10.4028/www.scientific.net/amm.824.218.

6. Kerndl, M., \& Steffan, P. (2017). Intelligent radiant floor heating regulation system with wireless sensors. 2017 40th International Conference on Telecommunications and Signal Processing (TSP). doi: 10.1109/tsp.2017.8075936.

7. Klubal, T., \& Ostrý, M. (2014). Integration of PCMs and Capillary Radiant Cooling/Heating to Ensure of Thermal Comfort. Advanced Materials Research, 1041, 350-353. doi: 10.4028/www.scientific.net/amr.1041.350.

8. Liu, X., Shi, L., \& Li, Y. (2017). Simulation study on capillary asymmetric radiant heating system. Procedia Engineering, 205, 2215-2222. doi: 10.1016/j.proeng.2017.10.051. 